\title{
KEY COMPETENCES OF FUTURE GARMENT WORKERS: THE OFFER AND DEMAND IN THE LABOUR MARKET
}

\author{
Halyna Odnoroh, \\ Postgraduate Student of the Institute of Vocational Education and Training of NAES of Ukraine \\ http://orcid.org/0000-0003-4498-0816, e-mail:RGV.20.04@gmail.com
}

\begin{abstract}
.
Relevance: State standards for professional (vocational) education of such professions as "seamstress", "dressmaker", "cutter" reveal the content of essential professional competences of these professions, as well as list general (key) competences common to all three professions. They have led to the need to identify a separate list of key competences required by employers of garment enterprises for each profession.

Aim: analysis, comparison and generalization of the offer and demand for key competences of garment workers in the Ukrainian labour market; determination of personal qualities, demanded by modern employers of Ukrainian garment enterprises for such professions as "seamstress", "dressmaker", "cutter".

Methods: the paper has analyzed, compared and summarized 270 vacancies and 344 curricula vitae available on Ukrainian and international job search websites to determine the level of needs of Ukrainian employers in the garment industry for garment workers with key competences (www.work.ua, www.hh.ua, www.rabota.ua).

Results. The paper clarifies the statistical needs of employers of Ukrainian garment enterprises for seamstresses, dressmakers and cutters with key competences. It compares the offer and demand for garment workers and proves that they cannot adequately meet the needs of modern employers due to insufficient levels of their key competences. It highlights that dressmakers and cutters are the more in-demand workers with key competences and should work in the field of public services or a single production. It specifies the reasons for weak demand for well-developed personal qualities for such a profession as "seamstress". Besides, it compares the demand of the Ukrainian and global labour markets for soft skills of garment workers. It shows that international employers are more interested in soft skills, being aware of their importance. However, this process is still on the way in Ukraine.

Conclusions: the paper proves the interdependence between the need for well-developed personal qualities of skilled workers and types of profession and production. It reveals the role of garment workers' key competences in developing personal qualities required by Ukrainian garment enterprises for such professions as "seamstress", "dressmaker" and "cutter", as well as the connection between key and professional competences.
\end{abstract}

Keywords: key competences, professional competences, garment industry, skilled worker, professions "dressmaker", "cutter", "seamstress".

Introduction. Today, there are transformational processes in all spheres of life which affect the labour market. One can see how the ratings of "in-demand" professions and requirements for skilled workers are changing. Employers are becoming more and more interested in soft skills that are independent of an individual profession and closely related to personal qualities. Therefore, education must develop key (general, universal) competences and promote lifelong learning (The Ministry of Education and Science of Ukraine, 2018).

State standards for professional (vocational) education of such professions as "seamstress", "dressmaker", "cutter" reveal the content of essential professional competences of these professions, as well as list general (key) competences common 
to all three professions. They have led to the need to identify a separate list of key competences required by employers of garment enterprises for each profession.

Sources. According to the Recommendation of the European Parliament and of the Council "On key competences for lifelong learning", the latter are seen as a set of knowledge, skills and attitudes needed by all citizens for personal self-realization and development, active social life, social cohesion and employment (Verkhovna Rada Legislation of Ukraine, 2006).

The problem of developing key competences in future skilled workers is mostly considered in the context of a competency-based approach. Some think that key competences, aimed at developing critical thinking, reflection and determining one's position (Ovcharuk ed., 2004, pp. 10, 16, 46; Kravets, 2014), contribute to developing professional skills and professional career (Kravets and other, 2014; Lemeshko, 2018; Zakatnov, 2007; 2015; Yershova, 2018; Seredina, 2018; Yablunovska, 2018). The New Ukrainian School, proceeding from the Recommendation of the European Parliament and of the Council (EU), regards key competences as a combination of knowledge, types of thinking, skills, abilities and other personal qualities, which can ensure personal realization and lifelong success. Key competencies include communication in the national language; communication in foreign languages; mathematical literacy; competencies in science and technology; digital competency; lifelong learning skill; a sense of entrepreneurship; social and civic competencies; cultural awareness; environmental awareness and healthy lifestyles (The Ministry of Education and Science of Ukraine, 2016). Such researchers as O. Bazeliuk (2018), M.-O. Yershov $(2018$; 2019) and L. Petrenko (2017) focus on the dependence of successful professional career on the development of future skilled workers' digital competence.

State standards for professional (vocational) education of such professions as "seamstress" (2016), "dressmaker" (2016) and "cutter" (2016) indicate that general and professional competences imply "the ability of the individual to perform particular activities that is expressed through knowledge, understanding, skills and values". General competences for these professions are defined as follows: promptness in making right decisions in an emergency at work; ability to be responsible for professional activities; knowledge of professional terminology; ability to act in non-standard situations; ability to work in a team; adherence to professional ethics; conflict prevention.

The paper aims to analyze the offer and demand for key competences of garment workers in the Ukrainian labour market and determine the modern personal qualities required by employers of Ukrainian garment enterprises.
Methods: the paper has analyzed, compared and summarized 270 vacancies and 344 curricula vitae available on Ukrainian and international job search websites to determine the level of needs of Ukrainian employers in the garment industry for garment workers with key competences (www.work.ua, www.hh.ua, www.rabota.ua).

Results and discussion. The subject matter of analysis covers the vacancies and curricula vitae available on popular job search websites. The paper also studies employers' demand for garment workers with key competences, which they need for self-realization, employment, professional development and career success in the globalized society.

The analysis of vacancies for garment workers shows that $42 \%$ of employers are in need for seamstresses, dressmakers and cutters with professional and key competences, whereas $58 \%$ of employers focus only on professional competences or do not place requirements for future workers at all (see Fig. 1).

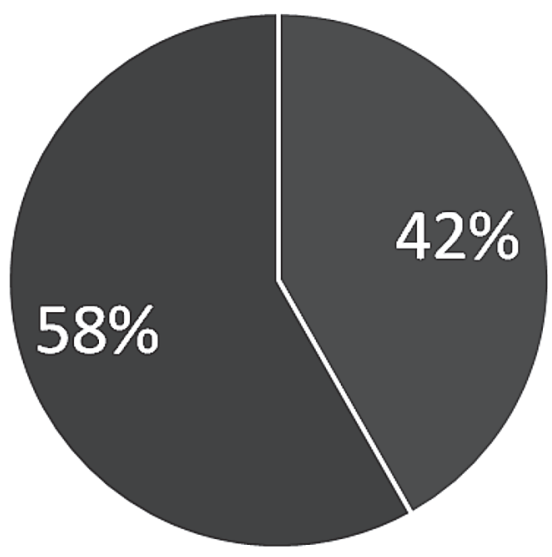

- vacancies with key competences

- vacancies with professional competences or without requirements

Fig. 1. Demand for workers with key competences

(Systematized based on the vacancies available on relevant websites between August, 14 and September, 4, 2019)

The paper clarifies that employers seek such soft skills as responsibility (courage in making independent decisions, responsibility for one's actions, personal standards) $-42.5 \%$; teamwork $-41.6 \%$; focus on learning, development and outcomes $33.6 \%$. Equally important are the following skills: time management (ability to organize one's work and time, punctuality) $-23.0 \%$; creativity (ability to think innovatively, apply advanced approaches to solving problems) - $17.7 \%$; communication skills (successful interaction with people, emotional intelligence) $15,9 \%$. Employers pay the least attention to focus on 
the customer $-8.0 \%$, multitasking $-8.0 \%$ and stress resistance $-3.5 \%$ (see Fig. 2).

The analysis of the demand for garment workers' key competences indicates different levels of requirements for seamstresses, dressmakers and cutters. The expectations of employers of garment enterprises regarding future workers' personal qualities prove that responsibility $(14.2 \%)$, teamwork $(11.5 \%)$, focus on development and outcomes (8.8\%) and time management (5.3\%) are the most critical skills, apart from professional ones, for seamstresses. These skills must ensure the continuity, speed and quality of making clothing in mass production. However, focus on the customer and stress resistance are not among the requirements at all. This may indicate the specificity of seamstresses' work associated with monotonous operations in the technological process.

Such skills as teamwork (16.8\%), responsibility (15.9\%), focus on development and outcomes (14.2\%) and time management $(8.8 \%)$ remain equally crucial for dressmakers. Recently, the demand for creativity $(8.8 \%)$ and communication skills $(6.2 \%)$ has been increasing. It is explained by the opportunity to work in dressmaker's studios, sewing workshops, where dressmakers not only perform technological operations on the sewing equipment but directly participate in the organization of production, ordering, communication with cutters or designers. However,

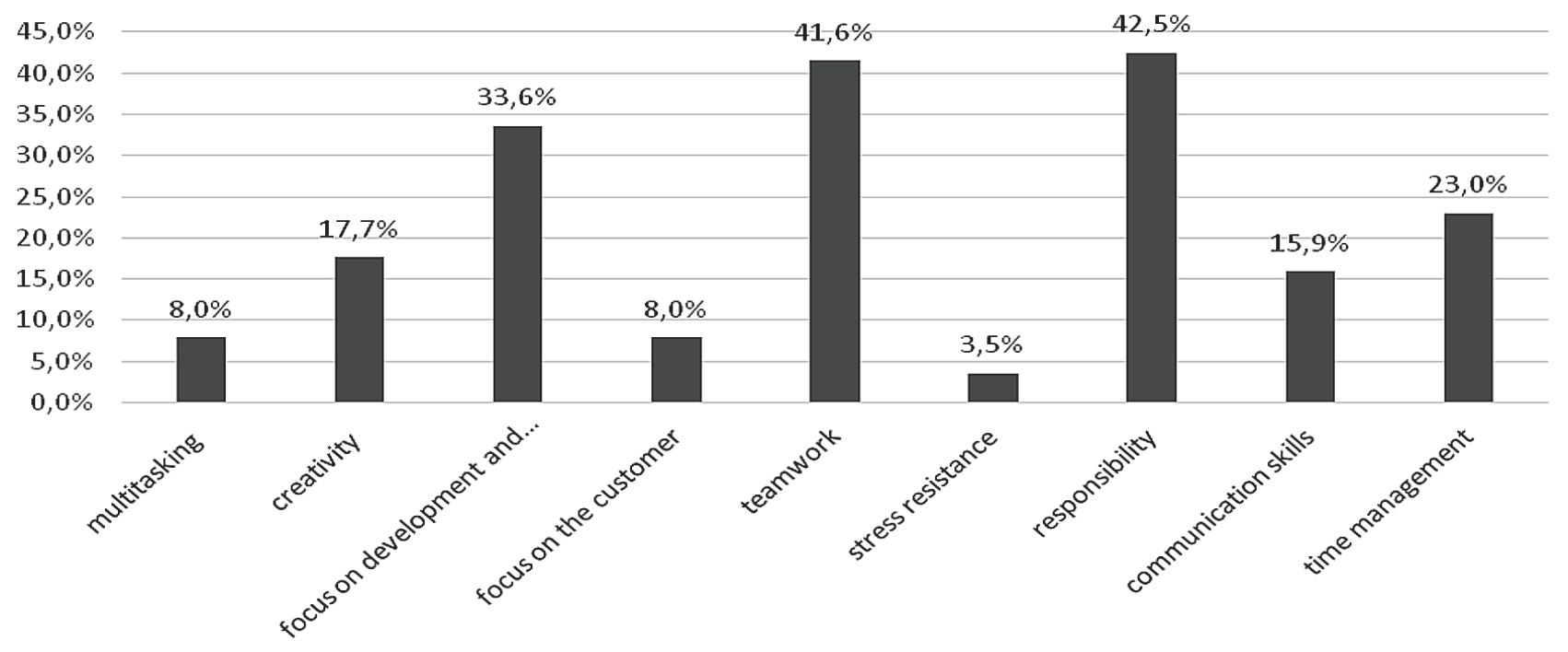

Fig. 2. Demand for the main key competences of garment workers in the labour market (Systematized based on the vacancies available on relevant websites between August, 14 and September, 4, 2019)

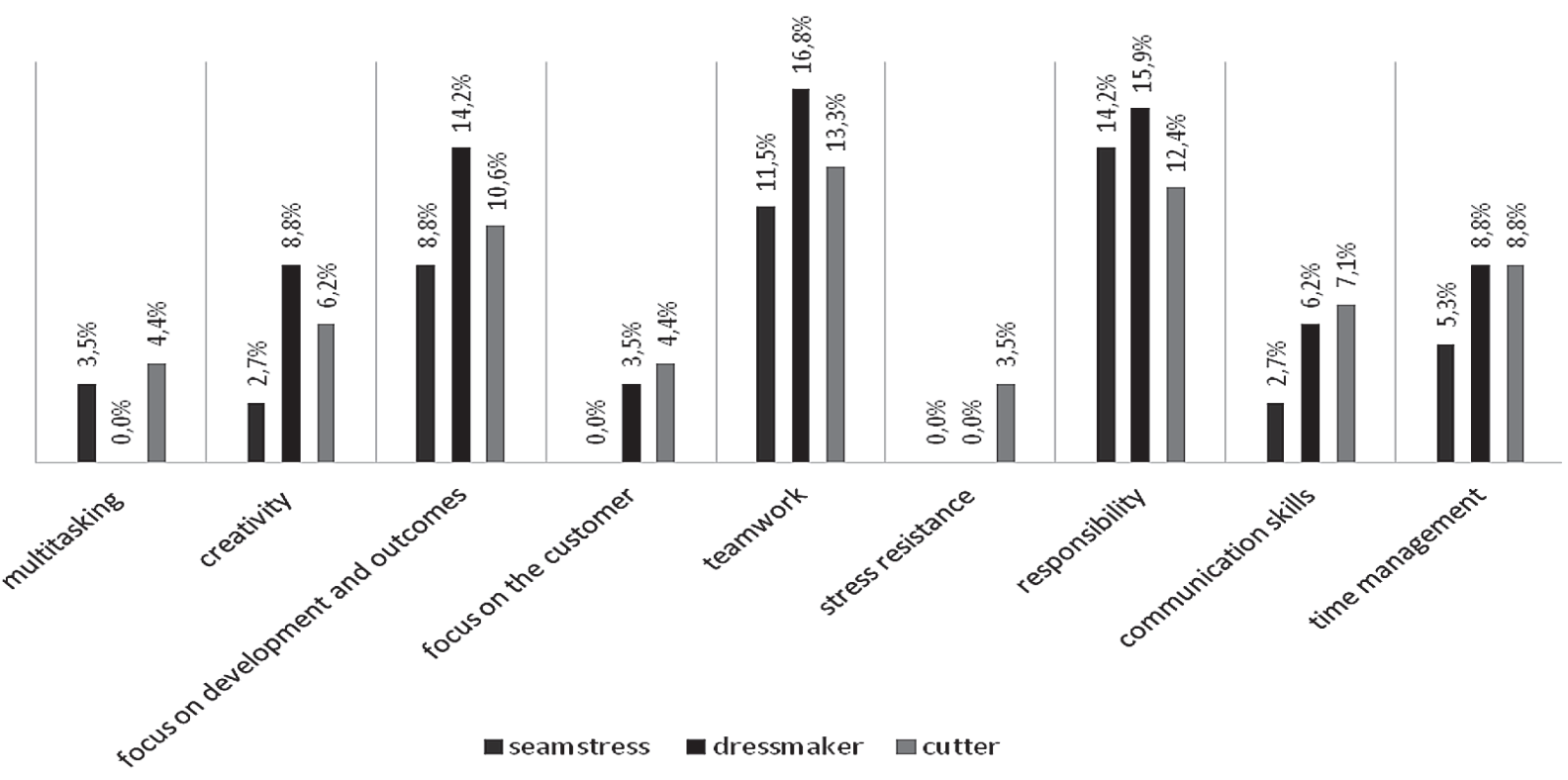

Fig. 3. Comparing the demand for key competences of seamstresses, dressmakers and cutters in the labour market (Systematized based on the vacancies available on Ukrainian job search websites between August, 14 and September, 4, 2019) 
employers do not require dressmakers to be capable of multitasking and stress resistance (see Fig. 3).

Teamwork (13.3\%), responsibility (12.4\%), focus on development and outcomes (10.6\%), time management (8.8\%), communication skills (7.1\%), creativity $(6.2 \%)$, multitasking (4.4\%), focus on the customer (4.4\%) and stress resistance (3.5\%) are rather fundamental skills for cutters (see Fig. 3). The increasing demand for the last four skills may be related to cutters' workload, responsibility and specificity of their work in mass production industries, where they cooperate with designers, technologists, supervisors of sewing workshops and teams of the cutting-out space, as well as public service enterprises, where they directly communicate with customers, designers, teams of dressmakers and finalize orders, being able to work with several products at the same time.

The analysis of the demand for garment workers with soft skills by type of production shows that dressmaker's studios, sewing shops, sewing workshops and small enterprises producing products for shops and brands place the most significant number of requirements for personal qualities of such workers. These are garment industries which have low capacity, work with small teams and produce products in a single copy or a limited quantity. Such activity requires individual and creative approaches to every order and customer, good organization and responsibility, team support and enables professional and personal realization. Managers of dressmaker's shops consider teamwork, responsibility $(23.0 \%)$ and focus on development and outcomes (17.7\%) as the essential skills. Creativity (13.3\%), time management $(13.3 \%)$, communication $(9.7 \%)$, and focus on the customer $(8.0 \%)$ are almost at the same percentage. Managers of small enterprises give the least impor- tance to multitasking $(4.4 \%)$ and stress resistance (1.8\%) (see Fig. 4).

Medium-sized enterprises with 25-75 employees, which specialize in a relatively stable product assortment, pay the most attention to teamwork (12.4\%). Responsibility (9.7\%) and focus on development and outcomes $(9.7 \%)$ represent the same percentage. Time management ( $8.0 \%$ ) and communication skills (5.3\%) are equally important. The minimum percentage is characteristic of multitasking $(2.7 \%)$ and creativity (2.7\%), whereas customer care skills and stress resistance are not considered important at all. It can be explained by the specific organization of production and technological processes in mass production industries, where workers perform specific operations and do not need to apply creative and individual approaches.

Mass production industries aim to ensure a permanent, fast and high-quality process of producing a large number of products. Therefore, they pay more attention to professional skills and promptness such as responsibility (9.7\%), focus on development and outcomes $(6.2 \%)$, teamwork (6.2\%) and less attention to time management $(1.8 \%)$, creativity $(1.8 \%)$, communication skills $(0.9 \%)$, stress resistance $(0.9 \%)$ and multitasking (0.9\%). Weak demand for customer care skills ( $0 \%$ ) reflects the lack of need for this skill in skilled workers in mass production.

The analysis of curricula vitae available on job search websites (www.work.ua, www.hh.ua, www. rabota.ua) indicates garment workers' low awareness of the importance of key competences. Only $16 \%$ of the analyzed curricula vitae contain a list of soft skills needed to succeed in the chosen profession (see Fig. 5).

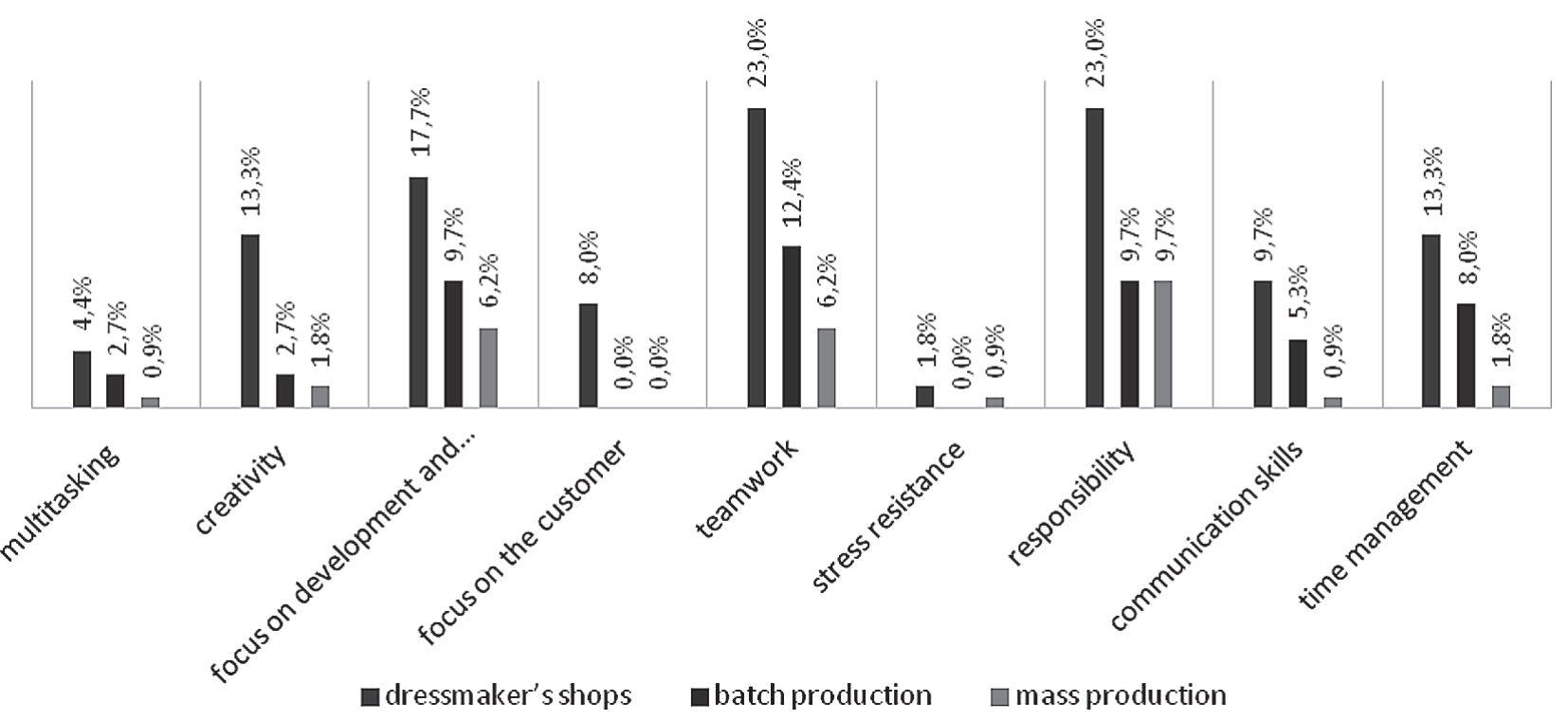

Fig. 4. Comparing the demand for the main key competences by type of production in the labour market (Systematized based on the vacancies available on relevant websites between August, 14 and September, 4, 2019) 


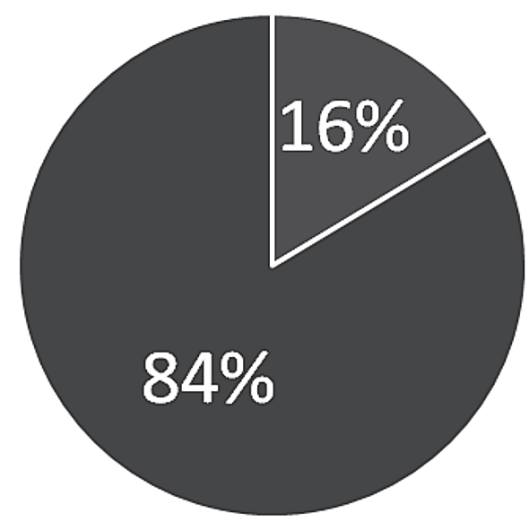

- curricula vitae with key competences

- curricula vitae with professional competences or without them

Fig. 5. The offer for workers with well-developed soft skills (Systematized based on the curricula vitae available on relevant websites between September 3 and 4, 2019)

The results of the available offers prove that, in addition to professional skills, applicants have such personal qualities as responsibility and personal standards (24.8\%), focus on development and outcomes (20.4\%), focus on the customer and communication skills (15.9\%), time management (10.6\%) and creativity $(9.7 \%)$. Recently, there has been an increase in the offers of computer literacy (7.1\%). However, it does not appear in the list of qualities demanded by employers of Ukrainian garment enterprises, which is probably explained by lack of digital skills in many employers and their low awareness of the importance of workers' digital culture. Still, the least developed skills among seamstresses, dressmakers and cutters are multitasking (3.5\%) and stress resistance (2.7\%) (see Fig. 6).

The study of garment workers' curricula vitae by profession shows that responsibility is more characteristic of cutters $(13.3 \%)$ and less characteristic of dressmakers (7.1\%) and seamstresses (4.4\%). Focus on development and outcomes is equally common for dressmakers and cutters (8.0\%). Focus on the customer is equally important (for dressmakers $6.2 \%$, cutters $-8.0 \%$ ). Communication skills prevail in curricula vitae of dressmakers $(8.8 \%)$, being slightly less standard for seamstresses $(4.4 \%)$ and cutters $(2.7 \%)$. Cutters focus on creativity $(6.2 \%)$ and time management (5.3\%). Computer literacy, as an essential aspect of professional performance and career growth, is characteristic of only $4.4 \%$ of dressmakers and $2.7 \%$ of cutters. Most importantly, this skill enables garments workers to achieve rapid career advancement, namely from the position of a dressmaker to the position of an operator of cutting tools in batch or mass production industries and an operator of computer-aided design (CAD) software in all types of production.

Emphasizing the demand for computer literacy, job seekers mostly refer to the ability to work with MS Office and CAD software, which helps to automatize the elaboration of technical design documentation required to launch the model into production. Multitasking and (seamstresses $-0 \%$, dressmakers, cutters $-1.8 \%)$ and stress resistance $(0.9 \%)$ are not given much importance in both curricula vitae and position

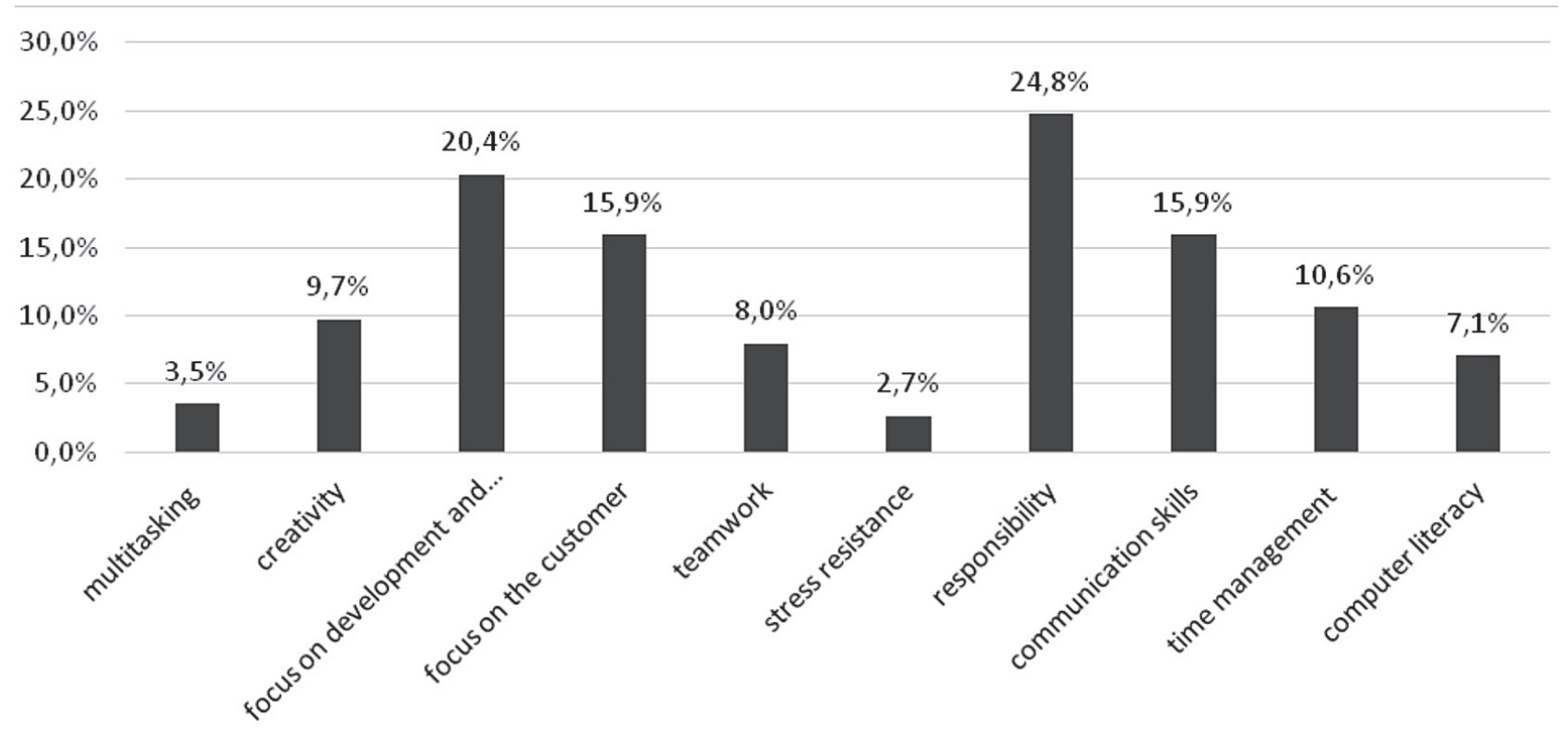

Fig. 6. The offer for the main key competences of garment workers in the labour market

(Systematized based on the curricula vitae available on relevant websites between September 3 and 4, 2019) 
summaries. This determines the apparent need to raise both employers and skilled workers' awareness of the importance of these skills for the garment industry (see Fig. 7).

The analysis of offers by profession shows that a high percentage of soft skills is characteristic of the dressmakers and cutters, who intend to work in a single production (e.g., in the field of public services). Instead, seamstresses focus on professional skills, which in some way reflect the specific nature of this profession and meet the demand of employers.

The comparison of the offer and demand proves that garment workers cannot adequately meet the needs of employers due to the lack of key competences (see Fig. 8). Thus, it is necessary to take into account the global trends in the awareness of the proportions between hard and soft skills (Yershova, 2019, pp. 165). After all, soft skills are becoming increasingly necessary for a successful social life of the individual, his or her self-realization and career growth.

The paper analyzes 53 vacancies available on international job search websites (www.tyba.com, www. adzuna.co.uk) to study the demand for garment workers with soft skills and determine the requirements placed by employers on these professions abroad.

The analysis of vacancies available on international job search websites shows that $38 \%$ of employers place requirements for key competences of future workers (see Fig. 9).

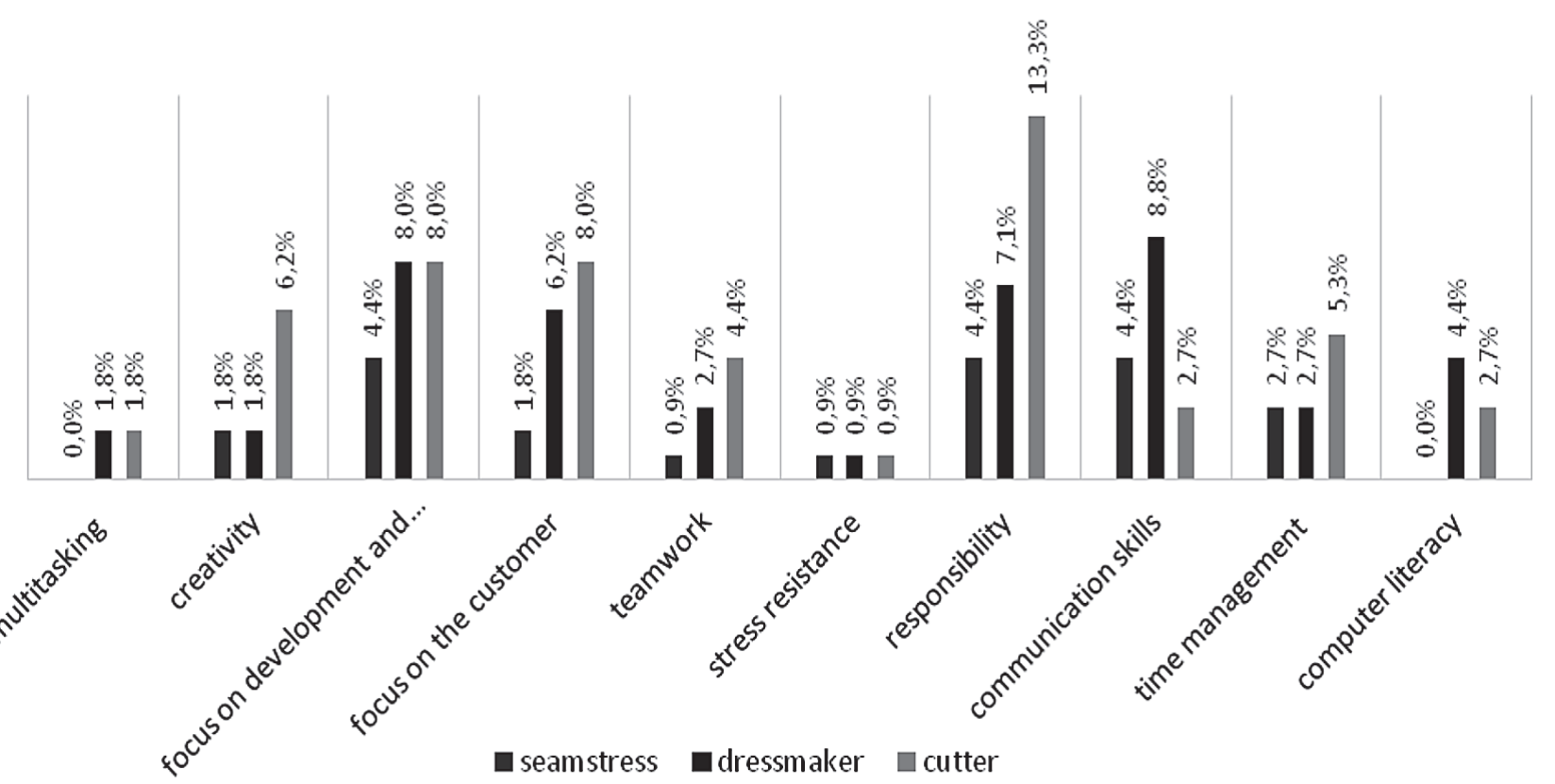

Fig. 7. Comparing the offers for key competences of seamstresses, dressmakers and cutters in the labour market (Systematized based on the curricula vitae available on relevant websites between September 3 and 4, 2019)

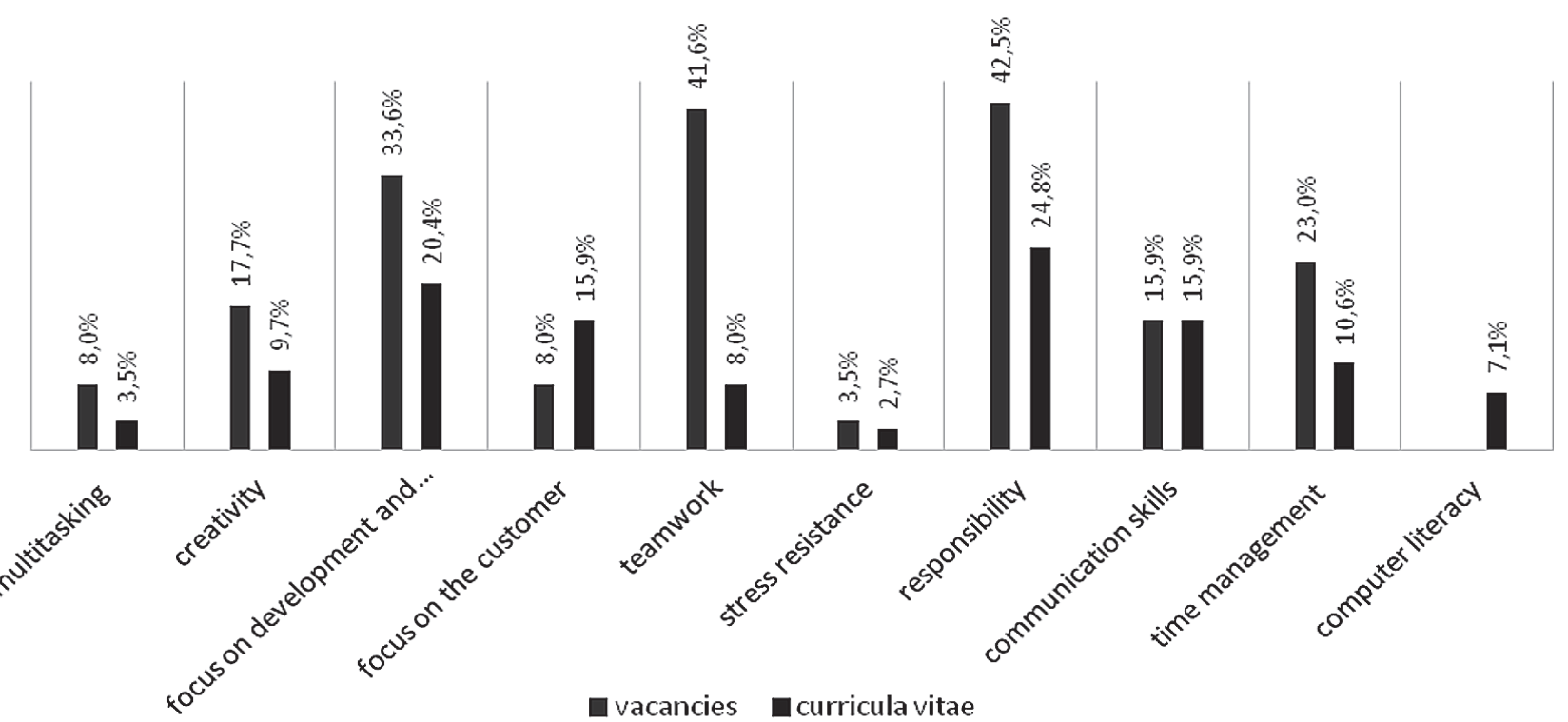

Fig. 8. Comparing the offer and demand for the main key competences of seamstresses, dressmakers and cutters in the labour market (Systematized based on the vacancies and curricula vitae available on relevant websites between August 14 and September 4, 2019) 


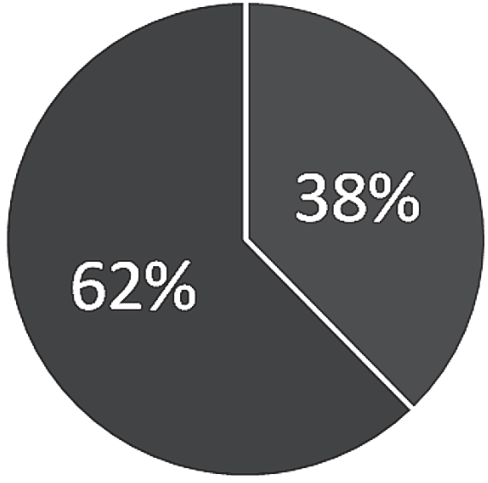

- vacancies with key competences

- vacancies with professional competences or without requirements

Fig. 9. The demand for workers with soft skills abroad (Systematized based on the vacancies available on international websites between September 6 and 8, 2019)

International employers focus on positive thinking, attention to detail, activity and initiative, rationality. Part of the vacancies offers traineeships to students along with their studies or during holidays, inviting them to assist in the production of collections for small design studios (brands) and world-renowned companies (Hugo Boss, Ralph Lauren, H\&M, Levi's). This allows future graduates not only to enhance their professional skills but also to develop soft skills, immersing themselves in a creative atmosphere, working with designers, highly skilled dressmakers and tailors.

Besides, international employers pay much attention to soft skills of future workers, especially teamwork. This requirement is contained in $70 \%$ of the analyzed vacancies (see Fig. 10).

Responsibility (65\%) and multitasking (60\%) account for almost the same percentage. Communication skills and focus on development and outcomes (45\%) are equally important. Creativity (30\%) and stress resistance $(35 \%)$ are found in vacancies for both mass and single production. Employers' requirements for focus on the customer (25\%), time management and computer literacy (20\%) are also quite significant. In the context of computer literacy, employers highlight not only their ability to work with MS Office but also with Photoshop and Illustrator.

The comparison of the demand of Ukrainian and global labour markets for garment workers with key competences proves that Ukrainian employers of garment enterprises, especially in the field of public services and single production, consider soft skills only as additional qualities of their workers. Position summaries demonstrate the need for workers with such skills as responsibility $(42.5 \%)$, teamwork (41.6\%), focus on development, outcomes and learning (33.6\%), time management $(23.0 \%)$, creativity $(17.7 \%)$ and communication skills $(15.9 \%)$. International employers, considering hard and soft skills equally important, are interested in team-

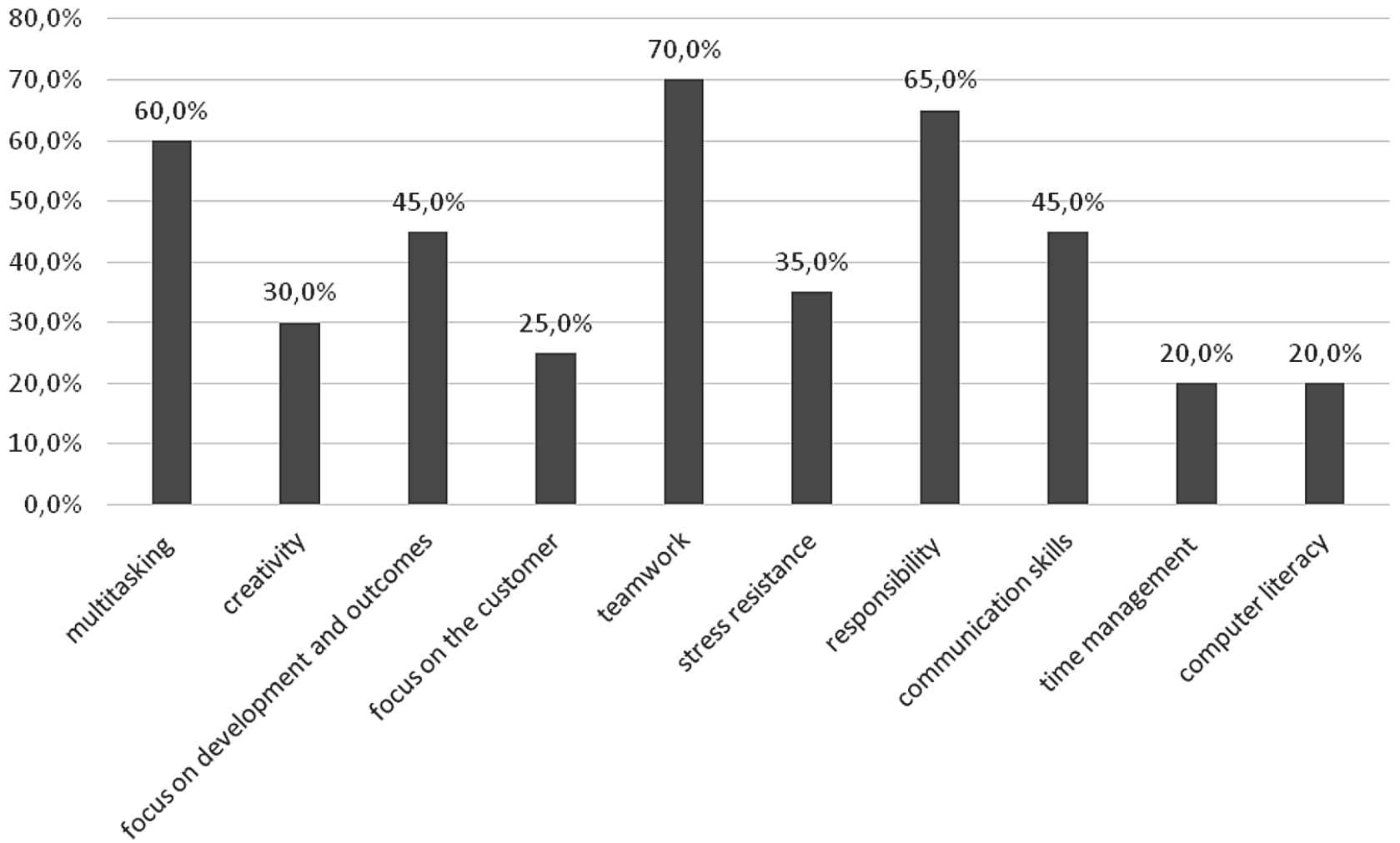

Fig. 10. The demand for soft skills of garment workers in the global labour market (Systematized based on the vacancies available on relevant websites between September 6 and 8, 2019) 
work (70.0\%), responsibility (65.0\%), multitasking (60.0\%), focus on development and outcomes and communication skills $(45.0 \%)$, stress resistance $(35.0 \%)$ and creativity $(30.0 \%)$. Time management and computer literacy (20.0\%) are also in demand. At the same time, Ukrainian employers are not at all interested in the latter. There is a noticeable difference between the demand of Ukrainian and international employers of garment enterprises for stress resistance (Ukraine $-3.5 \%$, abroad $-35.0 \%$ ) and multitasking (Ukraine $-8.0 \%$, abroad $-60.0 \%$ ). International employers pay far more attention to key skills since they have long been aware of their influence on the versatility and productivity of workers, ensuring the continuity of the working process, improving workers' ability to work at a rapid, intense pace, adequate response to the deadline (Yershov, 2019) (see Fig. 11).

Therefore, the essential objectives of professional education are the following: to train motivated, socially active and responsible workers, who strive for lifelong learning and are ready for professional and personal self-realization and career success.

Conclusions. The article justifies the interdependence between the need for well-developed personal qualities of skilled workers, types of a profession ("seamstress", "dressmaker", "cutter") and types of production. It shows that the most important key skills for seamstresses are responsibility, teamwork, focus on development and outcomes and time management, which ensure the continuity, speed and quality of mass production. The most important key skills for dressmakers are teamwork, responsibility, focus on development and outcomes, time management, creativity and communication skills, which is explained by the opportunity to work in dressmaker's studios, sewing workshops, where they not only perform technological operations on the sewing equipment but directly participate in the organization of production, ordering, communication with cutters or designers. The most important key skills for cutters are teamwork, responsibility, focus on development and outcomes, time management, communication skills, creativity, multitasking, focus on the customer and stress resistance related to the specifics of their work in mass-production industries, as well as in the field of public services.

The paper proves that employers of garment enterprises pay much attention to teamwork, responsibility, personal standards, focus on development and outcomes and time management. It also shows the increasing importance of communication skills, creativity, focus on the customer and multitasking in a single or small-scale production.

These skills are in demand for such professions as "dressmaker" and "cutter" in the field of public services. The demand for professional competences
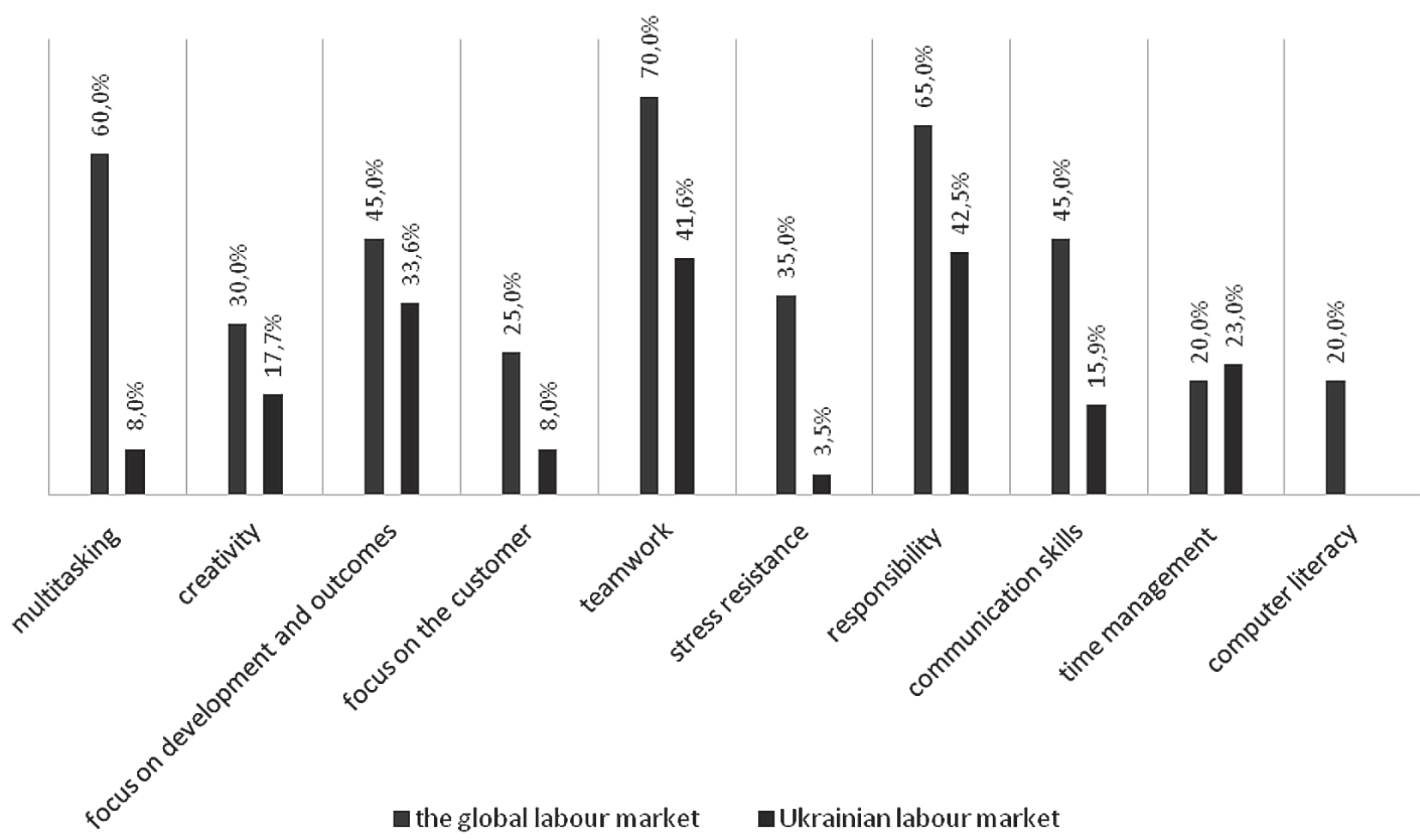

Fig. 11. Comparing the demand for the main soft skills of garment workers in Ukrainian and global labour markets (Systematized based on the vacancies available on relevant websites between August 14 and September 8, 2019) 
is stronger than for key competences in batch and mass-production garment industries since garment workers perform specific operations in the technological flow and are not motivated towards self-realization. It explains weak demand for well-developed personal qualities of seamstresses.

The article also reveals the significant percentage difference between the demand for soft skills in the Ukrainian and global labour markets. This is because the term "soft skills", as well as the need to develop key competences, have emerged relatively recently in Ukraine. Currently, transformational changes are underway in the system of requirements for future garment workers in Ukraine.

Further research should focus on studying the causes and ways to increase the attention of Ukrainian employers to the development of key competences in future garment workers.

\section{List of References}

Базелюк, О., 2018. Зміст і структура цифрової культури педагогічних працівників закладів професійної освіти. Науковий вісник Інституту професійно-технічної освіти НАПН Украӥни. Професійна педагогіка, 16, с. 81-87. https://doi.org/10.32835/2223-5752.2018.16.81-87.

Верховна Рада України. Законодавство України, 2006. Рекомендаиія 2006/962/ ЄС Європейського Парламенту та Ради (СС) «Про основні компетенщії для навчання протягом усього життя». [online] (Останнє оновлення 18 Грудень 2006) Доступно: <https://zakon.rada.gov.ua/laws/main/994_975> [Дата звернення 24 Листопад 2019].

Єршов, М.-О., 2018. Роль української ІТ-освіти на світовому ринку інформаційних товарів і послуг. Науковий вісник Інституту професійно-технічної освіти НАПН Украӥни. Професійна педагогіка, 16, c. 74-81. https://doi. org/10.32835/2223-5752.2018.16.74-81.

Єршова, Л., 2015. Формування референтної особистості як проблема освітньої практики сучасної України. Вісник Черкаського університету. Серія: Педагогічні науки, 6, с. 119-124.

Єршова, Л., 2018. Трансформація системи цінностей учнівської і студентської молоді в контексті реформування вітчизняної професійної освіти. Науковий вісник Інституту професійно-технічної освіти НАПН України. Професійна педагогіка, 16, с. 162-168. https://doi.org/10.32835/2223-5752.2018.16.162-168.

Закатнов, Д.О., 2007. Організаційно-педагогічне забезпечення підготовки учнівської молоді до планування кар'єри. Теоретико-методичні проблеми виховання дітей та учнівської молоді, 10 (II), с. 373-381.

Закатнов, Д., 2015. Профорієнтаційні засади кар'єрного розвитку учнівської молоді. Науковий вісник Інституту професійно-технічної освіти НАПН Украӥни. Професійна педагогіка, 9, с. 86-94.

Кравець, С. Г., 2014. Формування ключових компетентностей у процесі професійної підготовки майбутніх фахівців ресторанного сервісу: результати педагогічного експерименту. Професійна освіта: проблеми і перспективи, 6, с. 105-109.

Кравець, С. Г., Кравець, Ю. І., Дерев’янко, Н. П. та Оліферчук, О. Г., 2014. Педагогічні основи формування змісту підготовки кваліфікованих робітників за інтегрованими професіями: посібник. Київ: Поліграфсервіс.

Лемешко, Л., 2018. Формування художньо-творчої компетентності техніків- конструкторів одягу як проблема професійної педагогіки. Науковий вісник Інституту професійно-технічної освіти НАПН Украӥни. Професійна педагогіка, 16, с. 100-104. https://doi.org/10.32835/2223-5752.2018.16.100-104.

Міністерство освіти і науки України, 2016. Нова українська школа. Кониептуальні засади реформування середньої освіти [online] (Останнє оновлення 27 Жовтень 2016) Доступно: <https://mon.gov.ua/storage/app/media/zagalna\%20 serednya/nova-ukrainska-shkola-compressed.pdf $>$ (Дата звернення 20 Листопад 2019).

Міністерство освіти і науки України, 2018. Конщепиія розвитку педагогічної освіти [online] (Останнє оновлення 16 Липень 2018) Доступно: <https://mon.gov.ua/ua/npa/pro-zatverdzhennya-koncepciyi-rozvitku-pedagogichnoyi-osviti> [Дата звернення 26 Листопад 2019].

Міністерство освіти і науки. Міністерство соціальної політики, 2016. ДСПТО 7433. Професія: Кравещь. Київ: Видання офіційне. $72 \mathrm{c}$.

Міністерство освіти і науки. Міністерство соціальної політики, 2016. ДСПТО 7435. Професія: Закрійник. Київ: Видання офіційне. $71 \mathrm{c}$.

Міністерство освіти і науки. Міністерство соціальної політики, 2016. ДСПТО 7436. Професія: Швачка. Київ: Видання офіційне. $89 \mathrm{c}$.

Овчарук, О. В., ред., 2004. Компетентнісний підхід у сучасній освіті: світовий досвід та украӥнські перспективи [Бібліотека з освітньої політики]. Київ: К.І.С.

Однорог, Г., 2018. Теоретичні засади формування ключових компетентностей учнів у закладах професійної освіти засобами інтерактивних технологій. Науковий вісник Інституту професійно-технічної освіти НАПН України. Професійна педагогіка, 16, с. 104-109. https://doi.org/10.32835/2223-5752.2018.16.104-109.

Петренко, Л., 2017. Методи активного навчання: нові можливості дистанційної професійної освіти. Науковий вісник Інституту професійно-технічної освіти НАПН України. Професійна педагогіка, 14, с. 30-36. https://doi. org/10.32835/2223-5752.2017.14.30-36.

Радкевич, О.П., 2015. Розвиток правової компетентності педагогічних прачівників професійно-технічних навчальних закладів. Київ: ТОВ «НВП Поліграфсервіс».

Романова, Г., 2009. Психолого-педагогічна підготовка як чинник професійної самореалізації викладача економічного університету. Вісник Львівського університету, 3(25), с. 167-175. 
Середіна, I., 2018. Підприємницька компетентність майбутніх бакалаврів з економіки підприємства як науково-педагогічна проблема. Науковий вісник Інституту професійно-технічной освіти НАПН Украӥни. Професійна педагогіка, 16, с. 94-100. https://doi.org/10.32835/2223-5752.2018.16.94-100.

Яблуновська, К., 2018. Теоретичні основи формування екологічної компетентності майбутніх викладачів аграрних закладів вищої освіти. Науковий вісник Інституту професійно-технічної освіти НАПН Украӥни. Професійна педагогіка, 15, с. 47-53. https://doi.org/10.32835/2223-5752.2018.15.47-53.

Yershov, M.-O., 2019. Digitalisation of professional (vocational) and pre-high tertiary education of Ukraine: problems and prospects/ Scientific herald of the Institute of vocational education and training of NAES of Ukraine. Professional Pedagogy, 1(18), pp. 67-74. https://doi.org/10.32835/2223-5752.2019.18.67-74.

\section{Translated \& Transliterated}

Bazeliuk, O., 2018. Zmist i struktura tsyfrovoi kultury pedahohichnykh pratsivnykiv zakladiv profesiinoi osvity [Content and structure of digital culture of VET institutions' teachers]. Naukovyi visnyk Instytutu profesiino-tekhnichnoi osvity NAPN Ukrainy. Profesiina pedahohika [Scientific herald of the Institute of vocational education and training of NAES of Ukraine. Professional Pedagogy], 16, s. 81-87. https://doi.org/10.32835/2223-5752.2018.16.81-87, [in Ukrainian].

Verkhovna Rada Ukrainy. Zakonodavstvo Ukrainy [Verkhovna Rada of Ukraine. Legislation of Ukraine], 2006. Rekomendatsiia 2006/962/ YeS Yevropeiskoho Parlamentu ta Rady (IeS) «Pro osnovni kompetentsii dlia navchannia protiahom usoho zhyttia» [On the main competences for lifelong learning]. [online] (Ostannie onovlennia 18 Hruden 2006) Dostupno: <https://zakon.rada.gov.ua/laws/main/994_975> [Data zvernennia 24 Lystopad 2019], [in Ukrainian].

Yershov, M.-O., 2018. Rol ukrainskoi IT-osvity na svitovomu rynku informatsiinykh tovariv i posluh [The role of Ukrainian IT education in the world market of information products and services]. Naukovyi visnyk Instytutu profesiinotekhnichnoi osvity NAPN Ukrainy. Profesiina pedahohika [Scientific herald of the Institute of vocational education and training of NAES of Ukraine. Professional Pedagogy], 16, s. 74-81. https://doi.org/10.32835/2223-5752.2018.16.74-81, [in Ukrainian].

Yershova, L., 2015. Formuvannia referentnoi osobystosti yak problema osvitnoi praktyky suchasnoi Ukrainy [The reference individual formation as a problem of the educational practices in modern Ukraine]. Visnyk Cherkaskoho universytetu. Seriia: Pedahohichni nauky [Cherkasy university bulletin: Pedagogical sciences], 6, s. 119-124, [in Ukrainian].

Yershova, L., 2018. Transformatsiia systemy tsinnostei uchnivskoi i studentskoi molodi v konteksti reformuvannia vitchyznianoi profesiinoi osvity [Scientific herald of the Institute of vocational education and training of NAES Ukraine. Professional Pedagogy]. Naukovyi visnyk Instytutu profesiino-tekhnichnoi osvity NAPN Ukrainy. Profesiina pedahohika [Scientific herald of the Institute of vocational education and training of NAES of Ukraine. Professional Pedagogy], 16, s. 162-168. https://doi.org/10.32835/2223-5752.2018.16.162-168, [in Ukrainian].

Zakatnov, D.O., 2007. Orhanizatsiino-pedahohichne zabezpechennia pidhotovky uchnivskoi molodi do planuvannia kariery [Organizational and pedagogical support of training pupils to build a career]. V: Teoretyko-metodychni problemy vykhovannia ditei ta uchnivskoi molodi: zb. nauk. pr. [Theoretical and methodical problems in character building of children and pupils]. K.: In-t problem vykhovannia APN Ukrainy, s. 373-380, [in Ukrainian].

Zakatnov, D., 2015. Proforiientatsiini zasady kariernoho rozvytku uchnivskoi molodi [Professional orientation and proforientologic competences concerning vocational self-determination and career development of young students]. Naukovyi visnyk Instytutu profesiino-tekhnichnoi osvity NAPS Ukrainy. Profesiina pedahohika [Scientific herald of the Institute of vocational education and training of NAES of Ukraine. Professional Pedagogy], 9, s. 86-94, [in Ukrainian].

Kravets, S. H., 2014. Formuvannia kliuchovykh kompetentnostei u protsesi profesiinoi pidhotovky maibutnikh fakhivtsiv restorannoho servisu: rezultaty pedahohichnoho eksperymentu [Key competencies in the training of future specialists restaurant service results pedagogical experiment]. Profesiina osvita: problemy i perspektyvy [Vocational education: Problems and Prospects], 6, s. 105-109, [in Ukrainian].

Kravets, S. H., Kravets, Yu. I., Derevianko, N. P. ta Oliferchuk, O. H., 2014. Pedahohichni osnovy formuvannia zmistu pidhotovky kvalifikovanykh robitnykiv za intehrovanymy profesiiamy: posibnyk [The Pedagogical Principles of Building the Content of Training of Skilled Workers for Integrated Professions: a Textbook]. Kyiv: Polihrafservis, [in Ukrainian].

Lemeshko, L., 2018. Formuvannia khudozhno-tvorchoi kompetentnosti tekhnikiv-konstruktoriv odiahu yak problema profesiinoi pedahohiky [Forming clothes technicians-constructors' arts-creative competence as a professional pedagogy problem]. Naukovyi visnyk Instytutu profesiino-tekhnichnoi osvity NAPN Ukrainy. Profesiina pedahohika [Scientific herald of the Institute of vocational education and training of NAES of Ukraine. Professional Pedagogy], 16, s. $100-104$. https://doi.org/10.32835/2223-5752.2018.16.100-104, [in Ukrainian].

Ministerstvo osvity i nauky Ukrainy [Ministry of Education and Science of Ukraine], 2016. Nova ukrainska shkola. Kontseptualni zasady reformuvannia serednoi osvity [The New Ukrainian School. Conceptual Principles of secondary school reform] [online] (Ostannie onovlennia 27 Zhovten 2016) Dostupno: $<$ https://mon.gov.ua/storage/app/media/ zagalna\%20serednya/nova-ukrainska-shkola-compressed.pdf $>$ (Data zvernennia 20 Lystopad 2019), [in Ukrainian].

Ministerstvo osvity i nauky Ukrainy [Ministry of Education and Science of Ukraine], 2018. Kontseptsiia rozvytku pedahohichnoi osvity [The concept of teacher education development] [online] (Ostannie onovlennia 16 Lypen 2018) Dostupno: $<$ https://mon.gov.ua/ua/npa/pro-zatverdzhennya-koncepciyi-rozvitku-pedagogichnoyi-osviti $>$ [Data zvernennia 26 Lystopad 2019], [in Ukrainian].

Ministerstvo osvity i nauky. Ministerstvo sotsialnoi polityky [The Ministry of Education and Science of Ukraine. The Ministry of Social Policy of Ukraine], 2016. DSPTO 7433. Profesiia: Kravets [Profession: Dressmaker]. Kyiv: Vydannia ofitsiine. 72 s., [in Ukrainian].

Ministerstvo osvity i nauky. Ministerstvo sotsialnoi polityky [The Ministry of Education and Science of Ukraine. The Ministry of Social Policy of Ukraine], 2016. DSPTO 7435. Profesiia: Zakriinyk [Profession: Cutter]. Kyiv: Vydannia ofitsiine. 71 s., [in Ukrainian]. 
Ministerstvo osvity i nauky. Ministerstvo sotsialnoi polityky [The Ministry of Education and Science of Ukraine. The Ministry of Social Policy of Ukraine], 2016. DSPTO 7436. Profesiia: Shvachka [Profession: Seamstress]. Kyiv: Vydannia ofitsiine. 89 s., [in Ukrainian].

Ovcharuk, O. V., red., 2004. Kompetentnisnyi pidkhid u suchasnii osviti: svitovyi dosvid ta ukrainski perspektyvy [Biblioteka z osvitnoi polityky]. Kyiv: K.I.S, [in Ukrainian].

Odnoroh, H., 2018. Teoretychni zasady formuvannia kliuchovykh kompetentnostei uchniv u zakladakh profesiinoi osvity zasobamy interaktyvnykh tekhnolohii [Theoretical principles of development of the key competences of students at the vocational schools with the help of interactive technologies]. Naukovyi visnyk Instytutu profesiino-tekhnichnoi osvity NAPN Ukrainy. Profesiina pedahohika [Scientific herald of the Institute of vocational education and training of NAES of Ukraine. Professional Pedagogy], 16, s. 104-109. https://doi.org/10.32835/2223-5752.2018.16.104-109, [in Ukrainian].

Petrenko, L., 2017. Metody aktyvnoho navchannia: novi mozhlyvosti dystantsiinoi profesiinoi osvity [Methods of active learning: new opportunities for distance vocational education]. Naukovyi visnyk Instytutu profesiino-tekhnichnoi osvity NAPN Ukrainy. Profesiina pedahohika [Scientific herald of the Institute of vocational education and training of NAES of Ukraine. Professional Pedagogy], 14, s. 30-36. https://doi.org/10.32835/2223-5752.2017.14.30-36, [in Ukrainian].

Radkevych, O.P., 2015. Rozvytok pravovoi kompetentnosti pedahohichnykh pratsivnykiv profesiino-tekhnichnykh navchalnykh zakladiv [Development of legal competence of teaching staff of vocational schools]. Kyiv: TOV «NVP Polihrafservis», [in Ukrainian].

Romanova, H., 2009. Psykholoho-pedahohichna pidhotovka yak chynnyk profesiinoi samorealizatsii vykladacha ekonomichnoho universytetu [Psycho-pedagogical training as a factor in professional self-realization of lecturers at universities of economics]. Visnyk Lvivskoho universytetu [Herald of Lviv University], 3(25), s. 167-175, [in Ukrainian].

Seredina, I., 2018. Pidpryiemnytska kompetentnist maibutnikh bakalavriv z ekonomiky pidpryiemstva yak naukovopedahohichna problema [Entrepreneurship competence of future bachelors of the business economy as a scientific and pedagogical problem]. Naukovyi visnyk Instytutu profesiino-tekhnichnoi osvity NAPN Ukrainy. Profesiina pedahohika [Scientific herald of the Institute of vocational education and training of NAES Ukraine. Professional Pedagogy], 16, s. 94-100. https://doi.org/10.32835/2223-5752.2018.16.94-100, [in Ukrainian].

Yablunovska, K., 2018. Teoretychni osnovy formuvannia ekolohichnoi kompetentnosti maibutnikh vykladachiv ahrarnykh zakladiv vyshchoi osvity [Theoretical bases of forming the ecological competence of the agrarian higher education institutions' future academic staff]. Naukovyi visnyk Instytutu profesiino-tekhnichnoi osvity NAPN Ukrainy. Profesiina pedahohika [Scientific herald of the Institute of vocational education and training of NAES of Ukraine. Professional Pedagogy], 15, s. 47-53. https://doi.org/10.32835/2223-5752.2018.15.47-53, [in Ukrainian].

Yershov, M.-O., 2019. Digitalisation of professional (vocational) and pre-high tertiary education of Ukraine: problems and prospects. Scientific herald of the Institute of vocational education and training of NAES of Ukraine. Professional Pedagogy, 1(18), pp. 67-74. https://doi.org/10.32835/2223-5752.2019.18.67-74, [in English].

УДК 377.3:687]:005.336.2-027.561:331.5

\section{Ключові компетентності майбутніх кваліфікованих робітників швейного профілю: попит і пропозиція на ринку праці}

\section{Галина Однорог,}

аспірантка Інституту професійно-технічної освіти Національної академії педагогічних наук України

\section{Реферат.}

Актуальність. Державні стандарти професійної (професійно-технічної) освіти професій “швачка”, “кравець”, “закрійник” розкривають зміст професійних базових компетентностей даних професій, а також мають перелік загальних (ключових) компетентностей, спільних для всіх трьох професій. Це зумовило необхідність визначення для кожної професії окремого переліку ключових компетентностей, затребуваних роботодавцями швейних підприємств.

Mета: аналіз, порівняння й узагальнення попиту і пропозицій ключових компетентностей кваліфікованих робітників швейного профілю на вітчизняному ринку праці; визначення особистісних якостей, затребуваних сучасними керівниками вітчизняних швейних підприємств для професій “швачка”, “кравець”, “закрійник”

Методи: для визначення рівня потреби роботодавців швейної промисловості України у кваліфікованих робітниках з розвиненими ключовими компетентностями (далі - КК) було здійснено аналіз, порівняння та узагальнення 270 вакансій і 344 резюме, розміщених на вітчизняних і зарубіжних сайтах пошуку роботи (www. work.ua, www.hh.ua, www.rabota.ua).

Результати. Статистично проілюстровано потребу керівників українських швейних підприємств у швачках, кравцях та закрійниках зі сформованими ключовими компетентностями. Виконано порівняння попиту та пропозиції м'яких навичок робітників різних напрямів швейної промисловості, яке засвідчує той факт, що кваліфіковані робітники швейного профілю нездатні на сьогодні повністю задовольнити потреби роботодавців через недостатній рівень формування ключових компетентностей. Виявлено, що більш затребуваними робітниками із сформованими ключовими компетентностями є кравці та закрійники, які мають працювати у сфері побутового обслуговування населення або в одиночному виробництві. 3'ясовано причини низького рівня попиту на розвинені особистісні якості для професії “швачка”. Представлено порівняння попиту вітчизняного та світового ринків праці на гнучкі 
навички робітників швейної галузі, яке свідчить, що іноземні роботодавці надають вагомого значення розвиненим soft skills, усвідомлюючи їх важливість, а в Україні цей процес перебуває у стані формування.

Висновки: доведено існування взаємозалежності між потребою у розвинених особистісних якостях кваліфікованих робітників, видом професії і типом виробництва; відображено роль ключових компетентностей кваліфікованих робітників швейного профілю у формуванні особистісних якостей, затребуваних сучасними керівниками вітчизняних швейних підприємств для професій “швачка”, “кравець”, “закрійник”, а також взаємозв”язок між ключовими і професійними компетентностями.

Ключові слова: ключові компетентності, професійні компетентності, швейна галузь, кваліфікований робітник, професії “кравецьь”, “закрійник”, “ивачка”.

Received: 11 September 2019

Accept: 04 November 2019 